\title{
Development of A Policy Framework for the Growth of Biogas Technology using Poultry Droppings
}

\author{
P. O. Ayoola \\ African Institute for Science Policy and Innovation, \\ Obafemi Awolowo University, Ile-Ife, Nigeria
}

\begin{abstract}
This paper is used to develop a policy framework for the growth of biogas technology generally and particularly using poultry droppings as substrate. The poultry industry is one of the largest and fastest growing agro-based industries in the world. Biogas technology has been used to convert the organic waste from agriculture, livestock, industries, municipalities and other human activities into energy and manure. The study was carried out using a set of questionnaire. This set of questionnaire was administered on one hundred and eighty (180) poultry farmers in all the Southwestern States of Nigeria using snowball sampling technique. Data were collated and analyzed. The results show that about $3.4 \%$ on total average of the states used their poultry droppings to fill pot holes on access roads to their farms, about $19 \%$ of total average of the poultry farmers simply discarded their poultry droppings while only $3.4 \%$ of total average of the poultry farmers used theirs for biogas generation. It also revealed that International Development Agencies with mean of 2.06 was the most reported source of supports for the poultry farmers while local government accounted for the least supports with a mean of 1.22. In conclusion, the policy framework was developed to create awareness and benefit of poultry droppings to help create indigenous technology manufacturing capability and for job creation.
\end{abstract}

Keywords-- Biogas technology; Policy framework; Snowball sampling; Poultry droppings

\section{INTRODUCTION}

The poultry industry has emerged as the most commercialized and fastest expanding segment in the animal husbandry subsector. The increase in demand for poultry meat is majorly due to its acceptance by most societies and low cholesterol content $[1 ; 2 ; 3 ; 4$ and 5]. The introduction of commercial poultry in Nigeria has resulted in rapid evolutionary changes in the industry. The poultry outnumbers all other forms of livestock and is found throughout the country wherever there are human settlements [6]. The poultry industry also plays an important role in the development of the economy by providing employment opportunities [7]. The poultry industry in Lagos generates $\$ 44.88$ billion yearly and the industry produces 48 million crates of table eggs per annum, 14 million kilogrammes of broiler meat, two million cockerels, one million turkey birds and six million hatchable eggs [8 and 9]. However, this rapid growth of the poultry industry has raised concerns for poultry waste disposal [5]. Reference [10] reported that about 932.5 metric tonnes of commercial poultry manure is produced annually in Nigeria. Ammonia and greenhouse gases produced by poultry droppings have a negative impact on the environment [11]. The disposal and pollution problems caused by these poultry droppings could result to environmental problem unless sustainable management technologies are involved and employed [1].

The poultry industry in Nigeria has gone through series of developmental stages in the last forty years. The industry has witnessed tremendous progress in all areas. Gradually, the poultry keeping developed into a commercial enterprise involving thousands of birds. Large poultry units replaced small ones, while more efficient strains of birds, balanced feeds, intensive housing and better poultry equipment came into use. The industry however suffered a little set-back in the mid-80s as a result of feed crises, but today the industry is growing at a faster rate than before [12]. The poultry industry has many branches. The two main branches are egg and table meat production. The other branches include the production of chicks; point of lay pullets or ready to lay birds and of poultry feeds; the manufacturing of poultry equipment, and the processing or marketing of eggs and table birds [13]. Small farms accounted and still account for about $99 \%$ of all output of most livestocks and crops grown in Nigeria. The importance of the small scale farmers' contribution to national product and food is no longer in doubt. However, since these farmers depends on family and hired labour which often constitute over $60 \%$ of the total cash cost of production; the enterprises are run as family entities rather than business concern [13]. Poultry farmers face production problem such as high cost of inputs especially feed, drugs and chemicals. All these hinder the effective management of poultry industry and can result in reduction in the supply of products in market, hence affect the level of commercialization. However, this rapid growth of the poultry industry has also raised concerns for poultry waste disposal. Pathogenic microorganisms can thrive in poultry wastes. These constitute environmental and health hazards to livestock and the teeming human population [14].

\section{BIODIGESTER}

The biodigester is a physical structure where various chemical and microbiological reactions take place, it commonly known as the biogas plant. It is also known as bio-reactor or anaerobic reactor. The main function of this structure is to provide anaerobic condition within it. As a chamber, it should be air and water tight. It can be made of 
various construction materials and in different shape and size [15]. Construction of this structure forms a major part of the investment cost. Some of the commonly used designs are; Floating Drum Digester, Fixed Dome Digester, Deenbandhu Model, Bag digester, Plug flow digester, Anaerobic filter, Upflow anaerobic sludge blanket (UASB) [5]. The main factors that influence the selection of a particular design or model of a biogas plant are: economic, utilization of local materials, durability, suitability for the type of inputs, frequency of using inputs and outputs.

\section{BIOGAS}

Biogas is the mixture of gas produced by methanogenic bacteria while acting upon biodegradable materials in an anaerobic condition. It is mainly composed of 40 to 75 percent methane $\left(\mathrm{CH}_{4}\right), 25$ to 40 percent carbon dioxide $\left(\mathrm{CO}_{2}\right)$ and low amount of other gases. Though, there are mineral ions, heavy metals, detergents and some toxic materials that inhibit the normal growth of pathogens in the digester. Small quantity of mineral ions (e.g. sodium, potassium, calcium, magnesium, ammonium and sulphur) also stimulates the growth of bacteria, while very heavy concentration of these ions will have toxic effect. For example, presence of $\mathrm{NH}_{4}$ from 50 to $200 \mathrm{mg} / 1$ stimulates the growth of microbes, whereas its concentration above $1,500 \mathrm{mg} / 1$ produces toxicity. Similarly, heavy metals such as copper, nickel, chromium, zinc, lead, etc. in small quantities are essential for the growth of bacteria but their higher concentration has toxic effects.

Likewise, detergents including soap, antibiotics, organic solvents, etc. inhibit the activities of methane producing bacteria and addition of these substances in the digester should be avoided [5]. Although there is a long list of the substances that produce toxicity on bacterial growth, the inhibiting levels of some of the major ones are given in Table 1.

\section{SLURRY}

This is the residue of inputs that comes out from the outlet after the substrate is acted upon by the methanogenic bacteria in an anaerobic condition inside the digester. After extraction of biogas (energy), the slurry (also known as effluent) comes out of digester as by-product of the anaerobic digestion system. It is almost pathogen-free stabilized manure that can be used to maintain soil fertility and enhance crop production [5; 16 and 17].

Table 1: Toxic Level of Various Inhibitors

\begin{tabular}{|l|l|l|}
\hline $\mathrm{S} / \mathrm{N}$ & Inhibitors & $\begin{array}{l}\text { Inhibiting } \\
\text { Concentration }\end{array}$ \\
\hline 1 & Sulphate $\left(\mathrm{SO}_{4}^{--}\right)$ & $5.000 \mathrm{ppm}$ \\
\hline 2 & Sodium Chloride $(\mathrm{NaCl})$ & $40,000 \mathrm{ppm}$ \\
\hline 3 & Nitrate $(\mathrm{Calculated}$ as $\mathrm{N})$ & $0.05 \mathrm{mg} / \mathrm{ml}$ \\
\hline 4 & Copper $\left(\mathrm{Cu}^{++}\right)$ & $100 \mathrm{mg} / 1$ \\
\hline 5 & Chromium $\left(\mathrm{Cr}^{++}\right)$ & $200 \mathrm{mg} / 1$ \\
\hline 6 & Nickel $\left\{\mathrm{Ni}^{+++}\right)$ & $200-500 \mathrm{mg} / 1$ \\
\hline 7 & Sodium $\left(\mathrm{Na}^{+}\right)$ & $3,500-5,500 \mathrm{mg} / 1$ \\
\hline 8 & Potassium $\left(\mathrm{K}^{+}\right)$ & $2,500-4,500 \mathrm{mg} / 1$ \\
\hline 9 & Calcium $\left(\mathrm{Ca}^{++}\right)$ & $2,500-4.500 \mathrm{mg} / 1$ \\
\hline 10 & Magnesium $\left(\mathrm{Mg}^{++}\right)$ & $1,000-1,500 \mathrm{mg} / 1$ \\
\hline 11 & Manganese $\left(\mathrm{Mn}^{++}\right)$ & Above $1,500 \mathrm{mg} / 1$ \\
\hline
\end{tabular}

Slurry is found in different forms inside the digester as mentioned below:

- A light rather solid fraction, mainly fibrous material, which float on the top forming the scum;

- A very liquid and watery fraction remaining in the middle layer of the digester;

- A viscous fraction below which is the real slurry or sludge; and

- Heavy solids, mainly sand and soils that deposit at the bottom.

There is less separation in the slurry if the feed materials are homogenous. Appropriate ratio of urine, water and excrement and intensive mixing before feeding the digester lead to homogeneous slurry.

\section{USE OF BIOGAS}

Biogas technology is best suited to convert the organic waste from agriculture, livestock, industries, municipalities and other human activities into energy and manure [18]. Wellfunctioning biogas systems can yield a range of benefits for users, the society and the environment in general:

- Production of energy (heat, light, electricity);

- Transformation of organic wastes into high-quality fertilizer;

- Improvement of hygienic conditions through reduction of pathogens, worm eggs and flies;

- Reduction of workload, mainly for women, in firewood collection and cooking;

- Positive environmental externalities through protection of soil, water, air and woody vegetation;

- Economic benefits through energy and fertilizer substitution, additional income sources and increasing yields of animal husbandry and agriculture;

- Other economic and eco-benefit through decentralized energy generation, import substitution and environmental protection.

Biogas technology can substantially contribute to conservation and development, if the concrete conditions are favourable [9].

\section{FEDERAL GOVERNMENT POLICY}

The policy of the Federal Government had been to subsidize the pricing of locally consumed petroleum products, including electricity. In a bid to make the petroleum downstream sector more efficient and in an attempt to stem petroleum product consumption as a policy focus, the government has reduced and removed subsidies on various energy resources in Nigeria. The various policy options have always engendered price increases of the products [19]. With the restructuring of the power sector and the privatization of the electricity industry, it is obvious that for logistic and economic reasons especially in the privatized power sector, rural areas that are remote from the grid and/or have low consumption or low power purchase potential will not be attractive to private power investors. Such areas may remain unserved into the distant future [20].

Source: [5 and 16] 
Meanwhile, electricity is required for such basic developmental services such as pipe borne water, health care, telecommunications, and quality education. The poverty eradication, Universal Basic Education and Vision 20:2020 which are Federal Government transformation agenda programs require energy for success. The absence of reliable energy supply has not only left the rural populace socially backward, but has also left their economic potentials untapped. Fortunately, Nigeria is blessed with abundant renewable energy resources such as solar, wind, biomass, and small hydropower potentials. The logical solution is increased penetration of renewable into the energy supply mix (Sambo, 2008). The patterns of energy usage in Nigeria's economy can be divided into industrial, transport, commercial, agricultural, and household sectors [21]. The household sector accounts for the largest share of energy usage in the country - about $65 \%$. This is largely due to the low level of development in all the other sectors. The major energy-consuming activities in Nigeria's households are cooking, lighting, and use of electrical appliances. Cooking accounts for a staggering $91 \%$ of household energy consumption, lighting uses up to $6 \%$, and the remaining $3 \%$ can be attributed to the use of basic electrical appliances such as televisions and pressing irons [22].

The predominant energy resources for domestic and commercial uses in Nigeria are fuel wood, charcoal, kerosene, cooking gas and electricity [19]. Other sources, though less common, are sawdust, agricultural crop residues of corn stalk, rice husk, poultry droppings, cassava sticks, and, in extreme cases, cow dung. In Nigeria, among the urban dwellers, kerosene and gas are the major cooking fuels. The majority of the people rely on kerosene stoves for domestic cooking, while only a few use gas and electric cookers [23]. The energy consumption per capita in Nigeria is very small -about one-sixth of the energy consumed in developed countries. This is directly linked to the level of poverty in the country.

The electricity system in Nigeria centers on national electricity grid, which accounts for about $98 \%$ of the total electricity generation [24]. Power generation by other agencies such as the Nigerian Electricity Supply Company relies on thermal power for electricity generation unlike national electricity grid, which relies on both hydro- and thermal power. However, electricity is also a consumer of fuel and energy such as fuel oil, natural gas, and diesel oil. The importance of these sources of energy and fuel for generating electricity has been decreasing in recent years. Anaerobic digestion technology refers to the production of a combustible gas (biogas) and a digestate (biofertilizer) by the process called anaerobic digestion, which is the microbial degradation of organic matter under oxygen-free conditions. Using anaerobic digestion, biogas can be generated from readily available animal manure, crop residues, and industrial and municipal waste [25]

The 1999 Constitution of the Federal Republic of Nigeria places electricity generation, transmission and distribution on the Concurrent Legislative List. This allows all tiers of government to be involved in most aspects of the electricity supply industry [26]. In the case of biomass policies and their objectives, which state that:

\section{A. Biomass Policies:}

(i) The nation shall effectively harness non-fuelwood biomass energy resources and integrate them with other energy resources.

(ii) The nation shall promote the use of efficient biomass conversion technologies.

B. Objectives:

(i) To promote biomass as an alternative energy resource especially in the rural areas.

(ii) To promote efficient use of agricultural residues, animal and human wastes as energy sources.

(iii) To reduce health hazards arising from combustion of biomass fuel.

The Federal Government seeks to implement the policy in close partnership with other stakeholders, particularly state agencies and the private sector. The efficacy of these institutions and other agencies were provided to take responsibilities for the implementation of this policy. Hence a policy framework was provided [26].

\section{RESEARCH METHODOLOGY}

The study covered six (6) states in Southwestern Nigeria, namely Ekiti, Lagos, Ogun, Ondo, Osun and Oyo States. Information was collected using both primary and secondary sources. The primary source of information was through administration of questionnaire using snowball sampling technique, interview schedules, as well as personal observations of the poultry farms in the study area. Unstructured interviews were conducted in order to be familiar with what is obtainable in poultry farms and existing biogas technology. Photographs were also taken where necessary. The questionnaire was administered on the poultry managers. The secondary data were obtained from the literature, such as engineering and agricultural journals, textbooks, newspapers, magazines, the internet, published and unpublished research works and international reports from bodies such as United Nations Development Project, Food and Agriculture Organization, Consolidated Management Services, Nepal and articles on biogas generation from different countries. Thirty (30) poultry farms were purposively selected from each state for uniformity. The criteria for this selection was that each farm must have at least five hundred (500) birds in their poultry farms, therefore, a total of one hundred and eighty (180) poultry farms were purposively selected for the study.

\section{STUDY VARIABLES AND THEIR MEASUREMENTS}

i. The type of biodigesters used in the poultry farms were ticked (Floating Drum Digester, Fixed Dome Digester, Deenbandhu Model, Bag digester, Plug flow digester, Anaerobic filter, Upflow anaerobic sludge blanket (UASB).

ii. The institutional support(s) for the adoption of biogas technology was indicated on an eight item code; federal government, state government, local government, non-governmental organization (NGO), 
university, cooperative, bank and others. (measured on a four point Likert scale of: no support, moderate support, high support, very high support).

iii. Organizational source for funds (measured on a two item code; yes and no (if yes, provide the name(s) of the organization)).

\section{RESULTS AND DISCUSSION}

The Types of Biodigester Adopted by the Poultry Farmers

Table 2 showed the types of biodigester adopted by the poultry farmers. Though the number of poultry farms engaging in biogas technology is now increasing based on the level awareness during the course of study. About $2 \%$ of all the poultry farms visited were using bag biodigester, while $1.14 \%$ and $0.57 \%$ of the poultry farmers were using floating and fixed dome biodigester respectively. Majority of the poultry farms were not using these biodigesters because of the initial cost of purchasing them. The cost of materials and installation of a fixed type biodigester made the poultry farmers to opt for the bag biodigester and the floating biodigester [17]. A poultry farm visited using a bag biodigester cost about $\$ 1,500$. This cost will affect the number of years of use and the level of maintenance.

Table 2 Types of biodigester adopted by sampled poultry farmers

\begin{tabular}{|l|l|l|}
\hline Types of Biogas & Frequency & Percent (\%) \\
\hline Bag Digester & 3 & 1.71 \\
\hline Filter & 0 & 0 \\
\hline Deenbandhu Model & 0 & 0 \\
\hline $\begin{array}{l}\text { Khahi and Village Industries } \\
\text { Commission (KVIC) }\end{array}$ & 0 & 0 \\
\hline Floating & 2 & 1.14 \\
\hline Fixed Dome & 1 & 0.57 \\
\hline
\end{tabular}

Evaluation of the Rate of Support by Established Institutions/Agencies

Table 3 presents the mean distribution of the various sources of supports for adoption of biogas technology among the poultry farms in the Southwestern Nigeria. It revealed that International Development Agencies (mean = 2.06) was the most reported source of supports for the poultry farmers followed by supports from the federal government (mean $=$ 2.05), others include state government (mean $=1.84$ ), universities (mean $=1.74)$, NGOSs and agricultural support banks $($ mean $=1.65)$, cooperatives $($ mean $=1.34)$ while local government accounted for the least supports with a mean of (1.22). It means that for those farms that actually adopted biogas technology, most of them were motivated by the various supports as shown in the table. Besides, it is of high concern that the local government where most of these poultry farms were situated provided the least supports for the farmers.

This could mean that some of these local governments were not interested in agricultural or they do not have any willingness to support. Hence this calls for policy intervention and financial allocation for local government agricultural authorities as booster for more agricultural activities within the local governments. The availability of agricultural supports on the other hand, also serves as motivations for poultry farmers who are yet to adopt biogas technology since this will serve as motivation and booster for willingness to adopt the biogas technology in poultry farming.

Table 3 The Institutional supports for adoption of biogas technology among the poultry farms

\begin{tabular}{|l|l|l|}
\hline Support Parameter & $\begin{array}{l}\text { Mean } \\
\text { Rating }\end{array}$ & $\begin{array}{l}\text { Standard } \\
\text { Deviation }\end{array}$ \\
\hline International Development Agencies & 2.06 & 1.13 \\
\hline Federal Government & 2.05 & 0.97 \\
\hline State Government & 1.84 & 0.82 \\
\hline University & 1.74 & 0.99 \\
\hline Non-Governmental Organizations & 1.65 & 0.97 \\
\hline Banks & 1.65 & 0.80 \\
\hline Cooperatives & 1.34 & 0.59 \\
\hline Local Government & 1.22 & 0.48 \\
\hline
\end{tabular}

\section{THE POLICY FRAMEWORK FOR THE GROWTH OF} BIOGAS TECHNOLOGY IN POULTRY INDUSTRY

Figure 1 shows the proposed policy framework for the growth of biogas technology in poultry industry using poultry droppings. Firstly, this framework shows that government has a great influence in the adoption of biogas technology. The government has to create the policy and enabling environment to maximize the development of environmentally friendly (indigenous) energy resources in a most efficient manner to fully meet the energy requirements of the nation and to help the poultry farmers to meet the basic energy requirement of their farms. The government should link/collaborate with agencies, International and nongovernmental organizations to keep balance between energy development, environmental protection and enhancement of the environmental problems associated with energy supply and demand. Knowledge Institutions like Universities, Polytechnics, and Research institutions (National Agencies, National Technologies etc) are linked with these international and non-governmental organizations, and financial institutions (Banks, Cooperative and Mortgage banks etc.) to provide the support needed to establish the adoption of biogas technology in (A) part of the framework [17]. The knowledge Institutions (Universities, Polytechnics, Incubation centers etc.) will carry out the research and give the economic and environmental advantages of using the poultry droppings and will also help to promote cost effectiveness and environmental sensitive energy conservation and demand management practices in (B) part of the framework [5]. The finance institutions will also provide the poultry farmers to obtain loans to finance their set objectives which include the adoption of biogas technology. They are also available to provide the poultry farmers training on how to maximize the gains in adopting the biogas technology. The policy framework can change from time to time whether to increase the rate of adoption or to reduce it. This policy framework can also help to increase indigenous technology manufacturing capability and thereby provide jobs to the unemployed youth. 


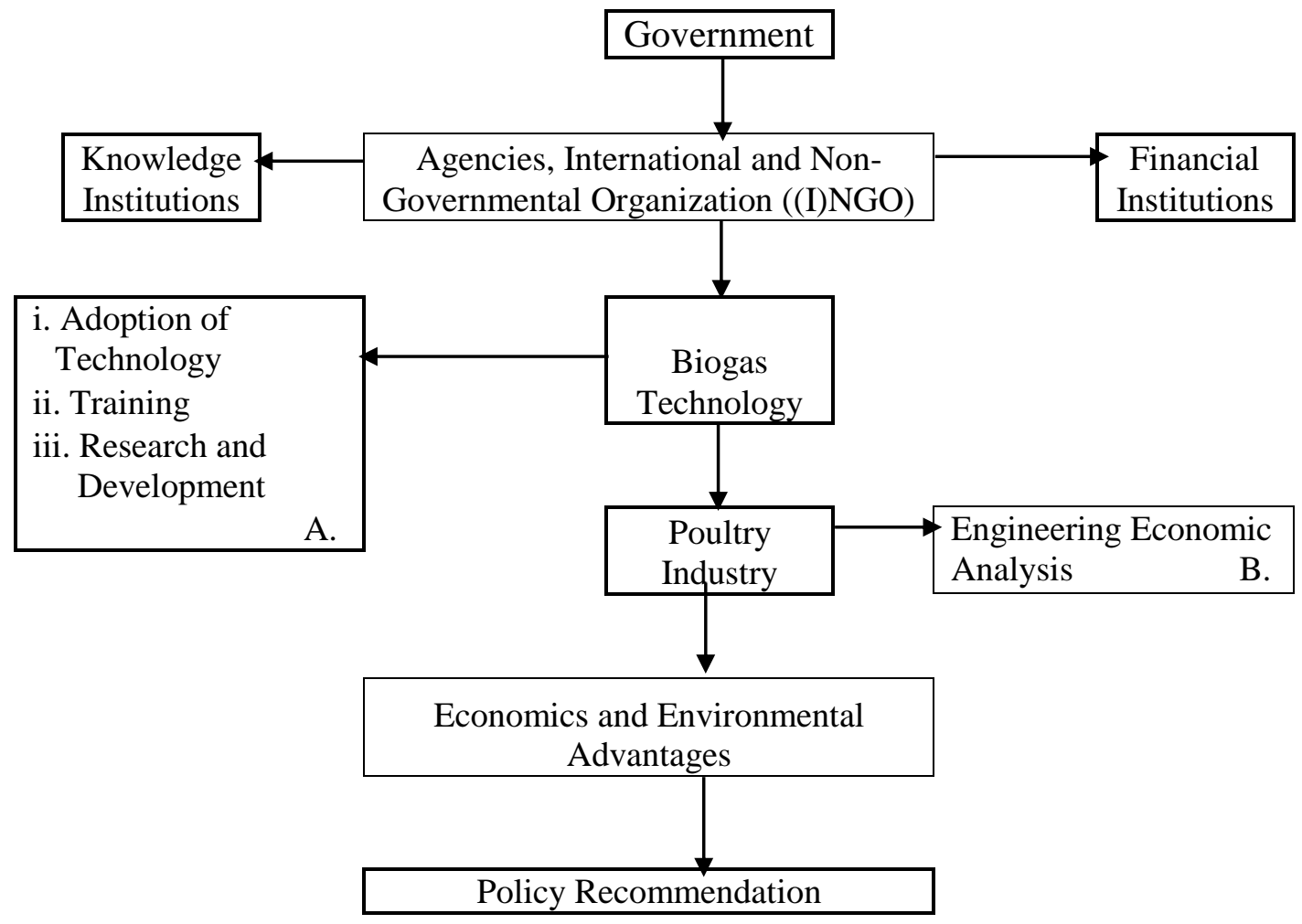

Fig. 1 The Proposed Policy Framework for the Growth of Biogas Technology by Poultry Industry

\section{CONCLUSION}

Over the years in Southwestern Nigeria, poultry industry has witnessed increase in quantities and the waste generated from this poultry industry has served as a source of energy using biogas technology (in terms of electricity and heat). The Institutional supports received by these poultry farmers were very small and the poultry farmers has to be sensitized with the usefulness

of this poultry waste. A policy framework was developed to create awareness and benefit of poultry droppings to help create indigenous technology manufacturing capability.

\section{POLICY RECOMMENDATIONS}

Based on the above conclusion, some recommendations are provided for policy intervention:

i. The state and local governments should be committed to the development and promotion of biogas technology to further emphasize the renewable energy policy of the federal government.

ii. There should be a proper planning and development of organic waste resources and biogas technologies at high levels with maximum participation of all the Institutional bodies.

\section{REFERENCES}

[1] J.F. Power, and W.A. Dick, Land Application of Agricultural, Industrial, and Municipal Byproducts, Soil Science Society of America Inc., Madison, WI. USA, 2000.

[2] B.P. Kelleher, J.J. Leahy, A.M, Henihan, T.F. O'Dwyer D. Sutton, and M.J. Leahy, Advances in Poultry Litter Disposal Technology - A Review. Bioresource Technology, 83: 27-36, 2002.
[3] A.N. Sharpley, S. Herron and T. Daniel, Overcoming the Challenges of Phosphorus-Based Management Challenges in Poultry Farming. Journal of Soil and Water Conservation, 58: 3038, 2007.

[4] H. Heinke, C. Alexandra, and T. Ludwig, The Poultry Market in Nigeria: Market Structures and Potential for Investment in the Market International Food and Agribusiness Management Review Volume 18 Special Issue A, Pg 197-222, 2015.

[5] P.O. Ayoola, I.O. Ogundari, A.O. Ayoola, J.B. Akarakiri and JF.K Akinbami, Techno-Economic Analysis of Poultry Droppings Fuelled Biogas Generation in Southwestern Nigeria, International Journal of Energy and Sustainable Development, 3(4): 72-80, 2018b.

[6] A.A. Adeyemo, and M.P. Onikoyi, Prospects and Challenges of Large Scale Commercial Poultry Production in Nigeria. Agricultural Journal, 7: 388-393, 2012.

[7] K.A. Akanni, Effect of Micro-finance on Small Scale Poultry Business in Southwestern. Nigeria. Emir. J. Food Agric., 19(2): $38-47,2007$.

[8] E. Daniel, Lagos Poultry Industry Generates 444.88 b. The Nation, 2013. http://thenationonlineng.net/new/lagos-poultryindustry-generates-n44-88b/. Accessed on 3rd, November, 2013.

[9] P.O. Ayoola, Techno-Economic Analysis of Biogas Generation from Poultry Droppings in Southwestern Nigeria, Ph.D. Thesis, Submitted to African Institute for Science Policy and Innovation, Obafemi Awolowo University, Ile-Ife, Nigeria, 2015.

[10] A.A Adewumi,, I.K. Adewumi, and V.F. Olaleye, Livestock Waste Menace, Fish Wealth Solution. Afr. J. Env: Sci Tec. 5: 149154, 2011.

[11] A. Meda, M. Hassouna, C. Aubert, P. Robin, and J.Y. Dourmand, Influence of Rearing Conditions and Manure Management Practices on Ammonia and Green House Gas Emissions from Poultry Houses. World's Poult. Sci. J., 67: 441-445, 2011.

[12] Eseigbe, B., Economic Analysis of Commercial Poultry Production in Selected Poultry Farms. B. Tech. Thesis, Department of Agricultural Economics and Extension Technology, Federal University of Technology, Minna, Nigeria, 2015. 
[13] Nmadu, J. N., Iwuajoku, R. C., and Jiya, E. Z., Commercialisation Level of Poultry Production in Minna Metropolis, Niger State, Nigeria. Asian J. Agr. Extens. Econ. Sociol, 1(1), 1-15, 2012.

[14] Musa, W. I., Sa'idu, L., Kaltungo, B. Y., Abubakar, U. B., and Wakawa, A. M., Poultry Litter Selection, Management and Utilization in Nigeria. Asian Journal of Poultry Science, 6(2): 4455, 2012.

[15] Khanal, S.K., Anaerobic Biotechnology for Bioenergy Production: Principles and Applications. Wiley-Blackwell Publishing, Ames, IA, USA, 2008.

[16] BTC Chengdu Biogas Research Institute, Chengdu, China, 1989.

https://energypedia.info/index.php/Biogas_ Technology_in_China. Accessed on 19th August, 2012.

[17] Ayoola, P.O., Ogundari, I.O., Akarakiri, J.B. and Akinbami, J.F.K., The Factors Affecting the Adoption of Biogas Technology in Poultry Industry in Southwestern Nigeria, European Journal of Advances in Engineering and Technology, 5(10): 768-774, 2018a.

[18] J. Yapp, CDM Potential for the Commercialization of the Integrated Biogas System. The International Seminar Technical Report on Biogas Technology for Poverty Reduction and Sustainable Development, October (18-20) Beijing, China, 2015.

[19] O.O. Famuyide, A.O. Adu, and M.O. Ojo, Socio-Economic Impacts of Deforestation in the Sudano-Sahelian Belt of Nigeria. Journal of Forestry Research and Management, 1(1\&2): 94-106, 2004.

[20] A.S. Sambo, Strategic Developments in Renewable Energy in Nigeria. International Association for Energy Economics. The Energy Journal, 4:15-19, 2009.

[21] ECN, National Energy Policy. Energy Commission of Nigeria, Federal Republic of Nigeria, Abuja, 2003.

[22] ECN, Renewable Energy Master Plan. Energy Commission of Nigeria, Federal Republic of Nigeria, Abuja, 2005.

[23] R. Abiodun, Fuel price Hike Spells Doom for Nigeria's Forest 2003.

[24] CBN, The Changing Structure of the Nigerian Economy and Implications for Development. A Report Prepared by Research Department, Central Bank of Nigeria; Realm Communications Ltd, Lagos, Nigeria, 2000

[25] Wilkie, A.C., The other Bioenergy Solution: The Case for Converting Organics to Biogas. Resource, Engineering and Technology for a Sustainable World, 13(8):11-12, 2006.

[26] FMPS, Renewable Electricity Policy Guidelines. Federal Ministry of Power and Steel, Federal Republic of Nigeria, 2006. www.iceednigeria.org. Accessed on 4th February, 2018. 